\title{
Non-cytotoxic Thymus capitata extracts prevent Bovine herpesvirus-1 infection in cell cultures
}

\author{
Ramzi Boubaker-Elandalousi ${ }^{1,2^{*}}$, Marwa Mekni-Toujani ${ }^{1}$, Belhassen Kaabi ${ }^{1}$, Imen Larbi ${ }^{1}$, Mohamed-Fethi Diouani ${ }^{1}$, \\ Mohamed Gharbi ${ }^{3}$, Hafidh Akkari ${ }^{3}$, Fatma B'chir ${ }^{4}$ and Abdeljelil Ghram
}

\begin{abstract}
Background: Bovine herpes virus type 1 (BHV-1) still causes great economic loss to the livestock industry and trade because there aren't any available drugs that proved to be fully effective against it. In this study, the cytotoxicity and the antiviral activities of the Thymus capitata extracts were evaluated for the development of new, non toxic and specific anti-herpesvirus drug. Aqueous extracts (AE), ethanolic extracts (EE) and essential oil (EO) of the aerial parts of Thymus capitata were analyzed to determine their chemical compositions by gas chromatography, and high performance liquid chromatography combined with mass spectrometry. Their cytotoxicity and antiviral activities against Bovine Herpesvirus type 1 (BHV-1) were evaluated by quantifying the reduction of the viral cytopathic effect using Madin-Darby Bovine Kidney cell line with colorimetric assay. T. capitata extracts were added at different stages of the viral infection to investigate and better quantify their potential inhibitory effects.

Results: Polyphenols and flavonoids were the major compounds found in T. capitata EO, EE and AE. The cytotoxic concentrations at 50\% were 48.70, 189 and $289 \mathrm{\mu g} \mathrm{ml}^{-1}$ for $E O, E E$ and $A E$, respectively. The inhibitor concentrations at $50 \%$ for the $E O, E E$ and $A E$, were $3.36,47.80$ and $164 \mu_{\mathrm{g} \mathrm{ml}}^{-1}$, respectively. The selectivity index anti-BHV-1 values were 14.49, 3.95 and 1.81 for EO, EE and AE, respectively. Thus, the EO extracts were the most efficient antiviral compounds. T. capitata extracts affect mainly the adsorption of BHV-1 virus to host cells.
\end{abstract}

Conclusion: T. capitata extracts inhibit the viral replication by interfering with the early stages of viral adsorption and replication. Thus, T. capitata is a potential candidate for anti-herpesvirus treatment.

Keywords: Thymus capitata, Cytotoxicity, Antiviral, Madin-Darby Bovine Kidney cell, Bovine Herpesvirus type1

\section{Background}

Bovine herpesvirus type 1 (BHV-1), a member of the subfamily Alphaherpesvirinae, is a virulent pathogen causing significant economic losses to the livestock industry, worldwide [1]. The virus is associated with a variety of symptoms including rhinotracheitis, vulvovaginitis, balanoposthitis, abortions, conjunctivitis and generalized systemic infections [2]. Infectious bovine rhinotracheitis (IBR), a wide spread enzootic herpetic infection caused by BHV-1, is classified in the list $\mathrm{B}$ of diseases by the Office International des Epizooties [2]. BHV-1-induced immunosuppression leads frequently to secondary bacterial infections.

\footnotetext{
* Correspondence: ramzi.b.landolsi@gmail.com

'Université Tunis El Manar, Laboratoire d'Epidémiologie et Microbiologie Vétérinaire, Institut Pasteur de Tunis, Place Pasteur BP 74, 1002 Tunis, Tunisia ${ }^{2}$ Université de la Manouba, Institut Supérieur de Biotechnologie, BiotechPôle, BP-66, 2020 Sidi Thabet, Tunisia

Full list of author information is available at the end of the article
}

Thus, BHV-1 is an important cofactor in the bovine respiratory disease complex which has great financial impacts $[1,2]$. Furthermore, BHV-1 has received increasing attention as a surrogate model for anti-herpes virus drug screenings. On the other hand, plant-derived antiviral extracts are of great interest for the development of new, non-toxic, more effective and specific anti-herpesvirus active molecules. Indeed, several trials using plant extracts have shown in vitro anti-BHV-1 activities at early and/or late stages of the viral replication, such as: Phyllanthus orbicularis [3], Erythroxylum deciduum, Lacistema hasslerianum (chodat), Xylopia aromatica [4], Heteropteris aphrodisiaca [5], Acacia nilotica (gum arabic tree) [6], Lippia graveolens (Mexican oregano or redbrush lippia) [7], Guettarda angelica (Velvetseed) [8], Prunus myrtifolia (West Indian cherry), Symphyopappus compressus [9], and Pimpinella anisum (Anise) [10]. 
A large number of plant extracts from Lamiaceae were also examined for their potential antiviral activity against herpesvirus, such as: Melissa officinalis (lemon balm), Mentha piperita (pepper-mint), Prunella vulgaris (prunella), Rosmarinus officinalis (rosemary), Salvia officinalis (sage) and Thymus vulgaris (thyme) [11-14]. Besides, different thyme species have been screened for antibacterial, anthelmintic, antifungal and antioxidant activities, and as immune modulator $[15,16]$. However, to the best of our knowledge, cytotoxic and antiviral activities of different T. capitata (Order of Lamiales, Family of Lamiaceae) extracts against BHV-1 have never been tested.

In the present study, we have determined the chemical compositions and the cytotoxicity effects of different extracts of the $T$. capitata areal parts, collected in Matmata region (Southern Tunisia). The aqueous (AE) and ethanolic extracts (EE) and the essential oil (EO) were tested, since significant differences in antimicrobial activities between these extracts have been previously reported $[11,12]$.

\section{Methods}

\section{Collection and preparation of the plant materials}

Fresh T. capitata plants were collected in June 2011 from Matmata locality in the South East of Tunisia $\left(33^{\circ}\right.$ $32^{\prime}$ North $9^{\circ} 58^{\prime}$ East). Aerial parts of the plants (leaves, stems and flowers) were separated, thoroughly rinsed in running tap water and air dried at room temperature during 14 days, then pulverized, grounded to fine powder and stored at $+4^{\circ} \mathrm{C}$ until use.

\section{Preparation of the extracts}

The AE and EE were prepared as previously described by Boubaker Elandalousi et al. [16]. The EO was prepared by dissolving $100 \mathrm{~g}$ of dried plant material in 1 liter of distilled water, and then submitted to microwave-assisted hydro-distillation at $+40^{\circ} \mathrm{C}$ during 4 hours, in a Clevengertype apparatus.

Stock solution $\left(10 \mathrm{mg} \mathrm{ml}^{-1}\right)$ of EO and EE were dissolved in Dulbecco's modified Eagle's cell culture medium (DMEM) with $0.5 \%$ dimethylsulfoxide (DMSO). All extracts were sterilized by filtration $(0.22 \mathrm{~mm}$ filter $)$, dried and kept in dark flask at $+4^{\circ} \mathrm{C}$ until tested.

\section{Analyses of $T$. capitata EO, EE and AE compositions EO and EE gas chromatography/mass spectrometry (GC/MS) analysis}

The GC-MS unit consists on a Perkin-Elmer Autosystem XL gas chromatograph, equipped with HP-5MS fused-5\% Phenyl Methyl Siloxane capillary column (Agilent, $30 \mathrm{~m} \times 0.25 \mathrm{~mm}$, film thickness $0.25 \mu \mathrm{m}$ ). It is interfaced with Perkin-Elmer Turbo mass spectrometer at specific operating conditions (injector temperature: $250^{\circ} \mathrm{C}$; carrier gas: Helium adjusted to a linear velocity of $37 \mathrm{~cm} \mathrm{~s}^{-1}$; flow

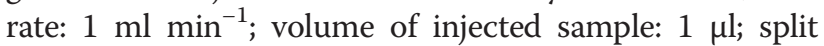

ratio: 50:1; ionization energy: $70 \mathrm{Ev}$; ion source temperature: $200^{\circ} \mathrm{C}$; scan mass range $\mathrm{m} \mathrm{z}^{-1}$ : 50-550 and interface line temperature: $300^{\circ} \mathrm{C}$ ).

\section{AE high performance liquid chromatography/mass spectrometry (HPLC/MS) analysis}

HPLC-MS (Agilent, Waldbronn, Germany) separation was performed using an Agilent C18 reverse-phase column $(150 \times 4.6 \mathrm{~mm})$ which was maintained at $33^{\circ} \mathrm{C}$, with a direct injection of $25 \mu \mathrm{l}$ of the extract at a 100 bars pressure and a flow rate of $0.25 \mathrm{ml} \mathrm{m^{-1 }}$. Elution was performed by gradient mode, using water and acetic acid $(999 / 1 \mathrm{v} / \mathrm{v})$, and acetonitrile in mobile phases. The gradient program was set to $5 \%$ for the 5 first minutes, increased linearly to $100 \%$ for 65 minutes, remained at $100 \%$ for three minutes and decrease to $5 \%$ during the last 69 minutes. Chromatographic peaks were investigated with Mass Lynx Software (Waldbronn, Germany).

The Mass spectroscopy (MS) was performed using a Micro mass Quattro Ultima PT MS model (Waldbronn, Germany) at the following operating conditions: capillary voltage $(3.20 \mathrm{kV})$; capillary temperature $\left(300^{\circ} \mathrm{C}\right)$; multiplier $(550 \mathrm{~V})$ and cone gas flow $\left(60 \mathrm{~L} \mathrm{Hr}^{-1}\right)$. The ion trap detector with electro-spray ionization source was used for quantification, and it was set in negative ionization mode.

Extracts constituents were identified by comparing their mass spectra or retention indices as HPLC-MS spectra with those of reference chemical compounds gathered from the Institut National de Recherches et d'Analyses Physico-chimiques, Tunisia - LMS library, and commercially available standards from published libraries.

\section{Cell line}

Monolayer cultures of MDBK cell line were grown in DMEM supplemented with $10 \%$ fetal calf serum, $100 \mathrm{IU} \mathrm{ml}^{-1}$ penicillin $\mathrm{G}$ and $100 \mathrm{mg} \mathrm{ml}^{-1}$ streptomycin. Two hundreds microliters of $1 \times 10^{6} \mathrm{ml}^{-1}$ cell suspension were put into each well of a 96-well culture plate, for both cytotoxicity and antiviral assays. All plates were maintained in an incubator at $37^{\circ} \mathrm{C}$ and $5 \% \mathrm{CO}_{2}$ atmosphere.

\section{Virus}

Stock virus of the Cooper-1 (Colorado-1) strain of BHV-1, obtained from the American Type Culture Collection (Rockville, MD, USA), was propagated in MDBK cell cultures. The infected cell supernatant fluids were harvested, titrated and stored at $-80^{\circ} \mathrm{C}$ until use.

For the virus titration, MDBK cells were seeded in 24-well culture plate and incubated at $37^{\circ} \mathrm{C}$. After 24 hours, serial dilutions of the virus stock were prepared in culture medium, and each dilution was added to 4 wells. After an additional 72 hours of incubation, the cytopathic effect (CPE) in each well was recorded. The viral Titer of BHV-1 
was calculated by Reed and Muench method, as described previously [17].

\section{Cytotoxicity assays}

To examine the effect of $T$. capitata extracts on the growth and the viability of the cultured cells, serial dilutions of extracts (from 5 to $500 \mu \mathrm{g} \mathrm{ml}^{-1}$ ) were prepared in DMEM, in triplicate, and $200 \mu \mathrm{l}$ of each dilution was added to the 96-well culture plates. The maximum nontoxic concentration (MNTC) was determined by cell morphology alterations, estimated under a light microscope at $\times 100$ magnifications during the 3 days incubation at $37^{\circ} \mathrm{C}$. Monolayer cells incubated with only DMEM were used as cell controls. The cells were fixed with $1 \%$ glutaraldehyde for $10 \mathrm{~min}$, stained with $0.1 \%$ crystal violet during $30 \mathrm{~min}$, and the optical density was determined by a spectrophotometer at $620 \mathrm{~nm}$ wavelength. The cell viability was calculated using the following formula:

$$
\begin{gathered}
\text { Cell viability }(\%)=100 \times\left(\operatorname{Abs}_{\text {sample }}-\mathrm{Abs}_{\text {cell free blank }}\right) \\
\qquad \mathrm{Abs}_{\text {mean media control }}
\end{gathered}
$$

\section{Abs: the absorbance}

The $50 \%$ cytotoxic concentration $\left(\mathrm{CC}_{50}\right)$ was calculated as the concentration causing 50\% cell death.

\section{Antiviral assays}

Only non cytotoxic and antiviral concentrations of each plant extract below the MNTC (EO: 2, 3, 4 and $5 \mu \mathrm{g} \mathrm{ml}^{-1}$; EE: 50, 55 and $60 \mu \mathrm{g} \mathrm{ml}^{-1}$ and AE: 160,170 and $180 \mu \mathrm{g} \mathrm{ml}^{-1}$ ) were tested to assess anti-BHV-1 activity.

To elucidate the mode of antiviral action, the MDBK cells were incubated with various plant extracts for 3 days, following 3 scenari: before and after viral infection, simultaneous infection.

\section{Cell culture pretreatment (before infection)}

Pre-treatment of cell cultures was performed by exposing the cell monolayers to different concentrations of the test compounds in maintenance medium $(200 \mu \mathrm{l})$ for 2 hours at $37^{\circ} \mathrm{C}$. After treatment, the cell monolayers were washed thoroughly with phosphate buffered saline (PBS), infected with $200 \mu \mathrm{l}$ BHV-1 suspension at $10^{3}$ Tissue Culture Infective Dose $50 \%\left(\mathrm{TCID}_{50}\right) \mathrm{ml}^{-1}$ of virus and observed for viral cytopathic activity during 72 hours incubation.

\section{Inhibition of virus attachment (simultaneous infection) assay}

BHV-1 suspension at a viral concentration of $10^{3} \mathrm{TCID}_{50}$ $\mathrm{ml}^{-1}$ of virus was mixed $(\mathrm{v} / \mathrm{v}: 100 \mu \mathrm{l})$ with different concentrations of the test extracts at room temperature.
Then, cells were incubated immediately with $200 \mu \mathrm{l}$ of the mixtures for 72 hours at $37^{\circ} \mathrm{C}$ and $5 \% \mathrm{CO}_{2}$ atmosphere.

\section{Post-infection assay}

Two hundred microliters of viral suspension at $10^{3}$ $\mathrm{TCID}_{50} \mathrm{ml}^{-1}$ in culture medium were adsorbed to MDBK cells for 2 hours at $37^{\circ} \mathrm{C}$. Cells were then washed with PBS, and the medium was replaced with $200 \mu \mathrm{l}$ DMEM containing the $\mathrm{EO}, \mathrm{EE}$ and $\mathrm{AE}$ of $T$. capitata at serial dilutions, which were then incubated for 72 hours at $37^{\circ} \mathrm{C}$ and $5 \% \mathrm{CO}_{2}$ atmosphere.

The controls consisted of untreated infected cells for virus control, confluent monolayer cells were infected with the virus at $10^{3} \mathrm{TCID}_{50} \mathrm{ml}^{-1}$ of virus; treated uninfected cells for plant extract controls; and untreated uninfected cells for cell control. After 3 days of incubation, the optical density (OD) was determined as previously described. The level of antiviral activity of the plant extracts was calculated using the following formula:

$$
\begin{aligned}
\operatorname{Antiviral} \text { activity }(\%)= & 100 \times\left(\mathrm{Abs}_{\text {sample }}-\mathrm{Abs}_{\text {virus control }}\right) \\
& /\left(\mathrm{Abs}_{\text {cell control }}-\mathrm{Abs}_{\text {virus control }}\right)
\end{aligned}
$$

The absorbance (Abs) of the virus control was calculated by mixing $100 \mu \mathrm{l} \times 10^{3}$ TCID50 of virus suspension with $100 \mu \mathrm{l}$ of culture medium without plant extracts. The absorbance of cell controls was estimated by mixing $100 \mu \mathrm{l}$ of MNTC of each extracts with $100 \mu \mathrm{l}$ of culture medium [18]. The 50\% effective antiviral concentration $\left(\mathrm{IC}_{50}\right)$ was calculated as the antiviral concentration causing 50\% inhibition of virus-induced CPE. The selectivity index (SI) was calculated as the ratio of $\mathrm{CC}_{50}$ and $\mathrm{IC}_{50}$.

\section{Statistical analysis}

The data are presented as means \pm standard deviation (S.D). The T-test was used to compare differences between mean groups. A correlation test between concentration extracts and viral inhibition was also performed. A p-value $<0.05$ was considered to imply statistical significance. The statistical analysis were performed using the $\mathrm{R}$ software for statistical computing (v3.01, available from: www.r-project.org), and GraphPad Prism software ${ }^{\ominus}$, release 3.0.

\section{Results}

The results of the chemical composition and the cytotoxic and antiviral activities of each plant extract are presented in Tables 1, 2, and 3, respectively.

\section{Chemical analysis of Thymus capitata EO, EE and AE}

A total number of 28 components were identified in $T$. capitata EO; phenols were the major constituents, mainly the 3-Methyl-4-isopropylphenol: thymol (73.38\%). Other 
Table 1 List of chemical compounds (descending order) in essential oil and ethanolic extract identified by GC-MS and in aqueous extract identified by HPLC-MS of Thymus capitata

\begin{tabular}{|c|c|c|c|}
\hline Molecule & $\begin{array}{l}\text { Essential } \\
\text { oil (\%) }\end{array}$ & $\begin{array}{l}\text { Ethanolic } \\
\text { extract (\%) }\end{array}$ & Aqueous extract \\
\hline $\begin{array}{l}\text { 3-Methyl-4- } \\
\text { isopropylphenol: thymol }\end{array}$ & 73.38 & 71.22 & $\begin{array}{l}\text { Apigenin-6,8- di } \\
\text { C-glucoside }\end{array}$ \\
\hline Camphor & ND & 17.18 & $\begin{array}{l}\text { Luteolin-7- } \\
\text { rutinoside }\end{array}$ \\
\hline Benzene & 10.86 & 6.32 & Hesperidin \\
\hline Caryophyllene & 2.55 & 1.11 & $\begin{array}{l}\text { Apigenin-7- } \\
\text { glucoronide }\end{array}$ \\
\hline Linalool & 1.97 & ND & $\begin{array}{l}\text { Eupafolin- } \\
\text { glucoside }\end{array}$ \\
\hline Caryophyllene oxide & 1.87 & 0.98 & $\begin{array}{l}\text { Acethyl- luteolin- } \\
\text { glucuronide }\end{array}$ \\
\hline 3-Cyclohexen-1-ol & 0.92 & 0.61 & Rosmarinic Acid \\
\hline 3-Cyclohexen-1-ol & 0.92 & ND & \\
\hline 1,6-Octadien-3-ol & ND & 0.83 & \\
\hline Eugenol & 0.81 & ND & \\
\hline Borneol & 0.78 & 0.64 & \\
\hline Beta.-Myrcene & 0.72 & 0.15 & \\
\hline Dimethyl Sulfoxide & 0.56 & ND & \\
\hline (+)-4-Carene & 0.50 & ND & \\
\hline 3 Hydroxy-1-octene & 0.41 & ND & \\
\hline $\begin{array}{l}\text { 4,5-epoxy-1-isopropyl-4- } \\
\text { methylcyclohexane }\end{array}$ & ND & 0.29 & \\
\hline Phenol & 0.28 & 0.26 & \\
\hline Phenol, 2,3,4,6-tetramethyl & 0.22 & ND & \\
\hline 3-Octanol & 0.20 & ND & \\
\hline 1,4-Cyclohexadiene & 0.18 & ND & \\
\hline Octahydrophenanthrene & 0.14 & ND & \\
\hline $\begin{array}{l}\text { 2,6,11,15-Tetramethyl- } \\
\text { hexadeca-2, 6,8,10, } \\
\text { 14-pentaene }\end{array}$ & 0.14 & ND & \\
\hline Naphthalene & 0.12 & ND & \\
\hline Alpha.-Caryophyllene & 0.12 & ND & \\
\hline Endo-Borneol & 0.11 & ND & \\
\hline Lopentadiene & 0.09 & ND & \\
\hline Trans-Linalool oxide & 0.05 & ND & \\
\hline Phenol Carvacrol & 0.04 & ND & \\
\hline Acetaminophenol & 0.04 & ND & \\
\hline Phenanthrene & 0.03 & ND & \\
\hline Total & 98.01 & 99.59 & \\
\hline
\end{tabular}

ND: Not detected.

compounds were also present but with lower concentrations such as caryophyllene (sesquiterpene, $2.55 \%$ ), linalool (monoterpene, 1.97\%), eugenol (phenol, 0.81\%) and borneol (monoterpene, 0.78\%). Aromatic hydrocarbons
Table 2 Cytotoxic activities of essential oil, ethanolic and aqueous extracts of Thymus capitata

\begin{tabular}{|c|c|c|c|}
\hline \multirow{2}{*}{$\begin{array}{l}\text { Concentration } \\
\left(\mu \mathrm{g} \mathrm{ml}^{-1}\right)\end{array}$} & \multicolumn{3}{|c|}{ Mean cell survival percentage \pm standard deviation } \\
\hline & $\begin{array}{l}\text { Essential oil } \\
(n=3)\end{array}$ & $\begin{array}{l}\text { Ethanolic extract } \\
(n=3)\end{array}$ & $\begin{array}{l}\text { Aqueous extract } \\
(n=3)\end{array}$ \\
\hline 5 & $100 \pm 1.03$ & $95.63 \pm 3.31$ & NA \\
\hline 10 & $93.50 \pm 1.13$ & $93.18 \pm 3.87$ & NA \\
\hline 20 & $84.51 \pm 1.59$ & $96.05 \pm 2.87$ & NA \\
\hline 50 & $47.42 \pm 0.64$ & $92.83 \pm 3.27$ & $100 \pm 0.74$ \\
\hline 100 & $14.77 \pm 0.07$ & $79.61 \pm 3.64$ & $92.21 \pm 2.41$ \\
\hline 200 & $2.91 \pm 0.03$ & $45.83 \pm 1.90$ & $74.20 \pm 1.71$ \\
\hline 300 & $1.63 \pm 0.05$ & $28.97 \pm 1.90$ & $48.35 \pm 1.21$ \\
\hline 500 & $1.21 \pm 0.04$ & $26.80 \pm 1.47$ & $28.68 \pm 0.38$ \\
\hline
\end{tabular}

NA: Not applicable.

(benzene, naphthalene, anthracen) and terpens (myrecen, caren) were also present in T. capitata EO with lower concentrations (Table 1).

Twelve compounds were identified in EE; most of them were phenols such as 3-Methyl-4-isopropylphenol or thymol (71.22\%), camphor (17.18\%), benzene (6.32\%) and caryophyllene (1.11\%) (Table 1).

Apigenin and luteolin derivatives were the most abundant phenolic compounds (flavonoid) found in AE, whilst rosmarinic acid was a minor one (Table 1 ).

Several phenolic components were present with roughly the same concentrations in both EO and EE, mainly 3-Methyl-4-isopropylphenol: thymol (73.38\% and 71.22\%, respectively) followed by benzene $(10.86 \%$ and $6.32 \%$, respectively).

\section{Cytotoxicity}

To examine the effect $T$. capitata extracts on the growth and the viability of cultured cells, EO, EE and AE were serially diluted and added to cell culture medium (Figure 1A).

The cytotoxicity effect was characterized by aggregation of degenerated cell clusters detaching from the bottom of the wells forming holes (gap formation) within the cell monolayer (Figure 1C). The results of cytotoxic effects of each plant extract are represented in Table 2. No effect was observed at the concentrations varying from 5 to $10 \mu \mathrm{g} \mathrm{ml}^{-1}$ for EO, 10 to $100 \mu \mathrm{g} \mathrm{ml}^{-1}$ for EE

Table 3 Antiviral activities of selected Thymus capitata extracts against bovine herpesvirus type1

\begin{tabular}{lllll}
\hline Extract & Yield $^{\mathbf{a}}(\%)$ & $\mathbf{C C}_{\mathbf{5 0}}{ }^{\mathbf{b}}\left(\boldsymbol{\mu \mathbf { g ~ m } ^ { - \mathbf { 1 } } )}\right.$ & $\mathbf{I C}_{\mathbf{5 0}}{ }^{\mathbf{C}}\left(\boldsymbol{\mu \mathbf { g ~ m l } ^ { - \mathbf { 1 } } )}\right.$ & $\mathbf{S I}^{\mathbf{d}}$ \\
\hline Essential oil & 1 & 48.70 & 3.36 & 14.49 \\
Ethanolic extract & 10.05 & 189 & 47.80 & 3.95 \\
Aqueous extract & 3.25 & 298 & 164 & 1.81 \\
\hline
\end{tabular}

$\mathrm{a}_{\%} \mathrm{w} / \mathrm{w}=\mathrm{g}$ of extracts $100 \mathrm{~g}^{-1}$ of dried and ground plant material.

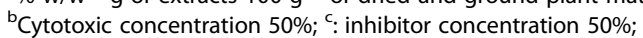

${ }^{\mathrm{d}}$ Selectivity index $=\mathrm{CC}_{50} / \mathrm{IC}_{50}$. 

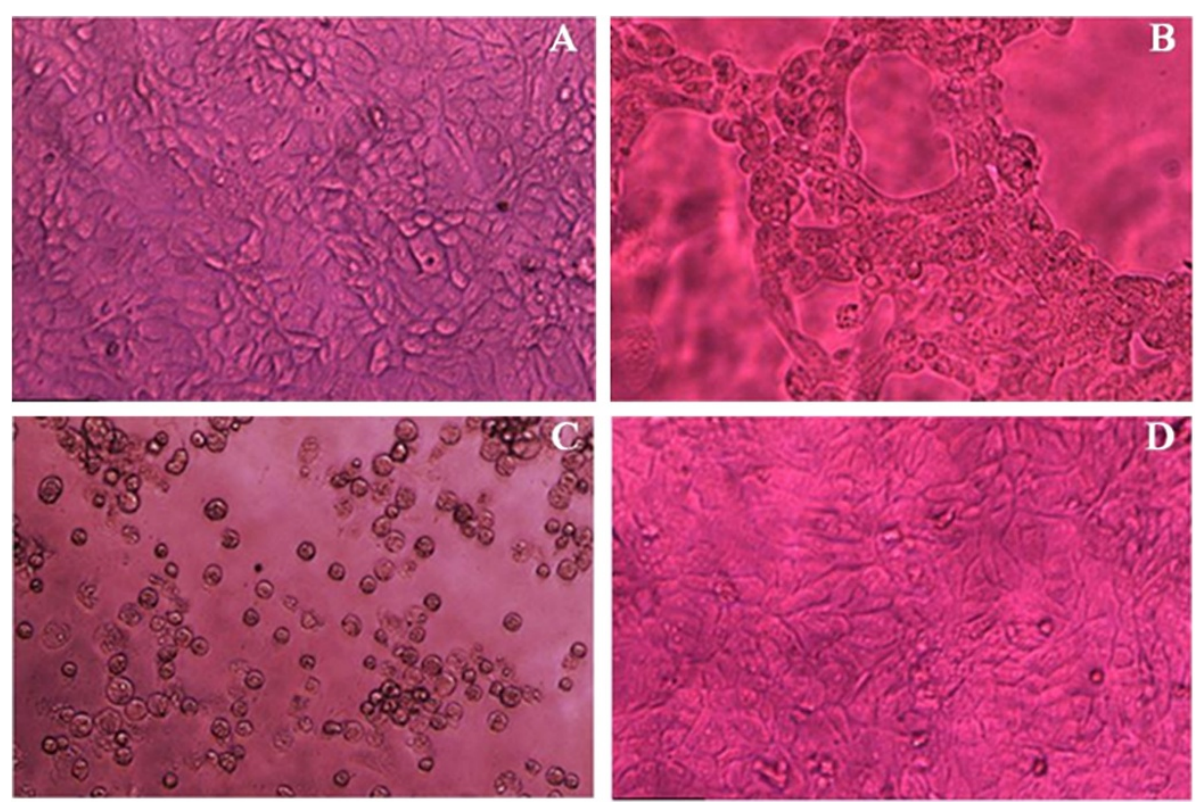

Figure 1 Cytotoxicity and cytopathic effects on Madin-Darby Bovine Kidney cells $(\times 100)$ after addition of EO, EE and EA of Thymus capitata before infection with $10^{3} \mathrm{TCID}_{50} \mathrm{ml}^{-1}$ of Bovine herpesvirus type 1 (BHV-1). A: Cell control, not infected with BHV-1, after 72 hours of incubation. B: Virus control (cytopathic effect), untreated MDBK cell culture, 72 hours after BHV-1 infection with $10^{3} \mathrm{TCID}_{50} \mathrm{ml}^{-1}$. C: Cytotoxic effect, MDBK treated with extracts of EO $\left(50 \mu \mathrm{g} \mathrm{ml}^{-1}\right), 72$ hours of incubation. D: Viral inhibition, MDBK cells were pre-treated with $\mathrm{EO}\left(5 \mu \mathrm{g} \mathrm{ml^{-1 }}\right)$ for $2 \mathrm{~h}$, then infected with BHV-1 at $10^{3} \mathrm{TCID}_{50} \mathrm{ml}^{-1}$.

and 5 to $200 \mu \mathrm{g} \mathrm{ml}^{-1}$ for $\mathrm{AE}$. The $\mathrm{CC}_{50}$ values determined by the colorimetric assay were $48.70 \mu \mathrm{g} \mathrm{ml}^{-1}, 189 \mu \mathrm{g} \mathrm{ml}^{-1}$ and $298 \mu \mathrm{g} \mathrm{ml}^{-1}$ for $\mathrm{EO}, \mathrm{EE}$ and $\mathrm{AE}$, for concentrations up to 10,100 and $200 \mu \mathrm{g} \mathrm{ml}^{-1}$ of EO, EE and $\mathrm{AE}$, respectively. Cytotoxicity was detected when degenerated cells become round and float in the medium with more prominent nuclei. The EO induced the highest cytotoxic effect, while $\mathrm{EE}$ and $\mathrm{AE}$ induced moderate and low cytotoxicity effect, respectively.

\section{Virus inhibition}

The viral CPE usually appeared within 3 days after inoculation. The CPE of BHV-1 is characterized by cell rounding and ballooning, forming grape-like clusters of spherical cells gathered around a gap in the monolayer. Sometimes, giant cells with several nuclei may be observed (Figure 1B).

At MNTC of plant extracts, viral CPE was significantly reduced ( $\mathrm{p}$-values $<0.05$ ) and the anti-BHV-1 activity showed a dose dependant response (Figure $2 \mathrm{~A}$ and $\mathrm{B}$ ). The $\mathrm{IC}_{50}$ were $3.36,47.8$ and $164 \mu \mathrm{g} \mathrm{ml}{ }^{-1}$ for EO, EE and $\mathrm{AE}$, respectively. According to the SI values, the highest antiviral activity was seen with EO followed by that of EE and AE (Table 3). Indeed, a high cytotoxic value and a low inhibitory concentration gave the highest selectivity index for EO, indicating that it is the most effective antiviral extract (Table 3).
When host cells were treated with extracts prior to infection, no CPE of $\mathrm{t}$ BHV-1 infection was observed (Figure 1D). Thus, pre-treatment of MDBK cells with T. capitata EO, EE and AE completely inhibited BHV-1 infectivity (p-value $<0.05$ ). However, when $T$. capitata $\mathrm{EO}, \mathrm{EE}$ or AE were added during or after virus penetration, the viral CPE of the BHV-1 was significantly reduced in a dose dependant manner (p-value $<0.05$ ) (Figure 2A; B).

A very significant correlation was found between $\mathrm{AE}$ concentration and viral inhibition in the interval [160, $180 \mu \mathrm{g} \mathrm{ml}^{-1}$ ] of AE concentration.

\section{Discussion}

The analyses of the composition of EO, EE and AE of Tunisian $T$. capitata revealed the predominance of phenolic compounds (Table 1). Thymol: 3-Methyl-4isopropylphenol was the major component found in both EO and EE. Caryophyllene was present in low concentrations in EO and EE. However, camphor, linalool, eugenol and borneol were only identified in EE and EO, respectively. Interestingly, $\mathrm{AE}$ exhibited the largest amount of apigenin- and luteolin as phenolic (flavones) compounds. In contrast, rosmarinic acid was found to be a minor compound in AE (Table 1). These findings are in accordance with those reported in previous studies on $T$. capitata from South Tunisia and other countries [14,19]. Mkaddem et al. [19] showed that the major EO compound in $T$. capitata was thymol, using plants from the same region. 

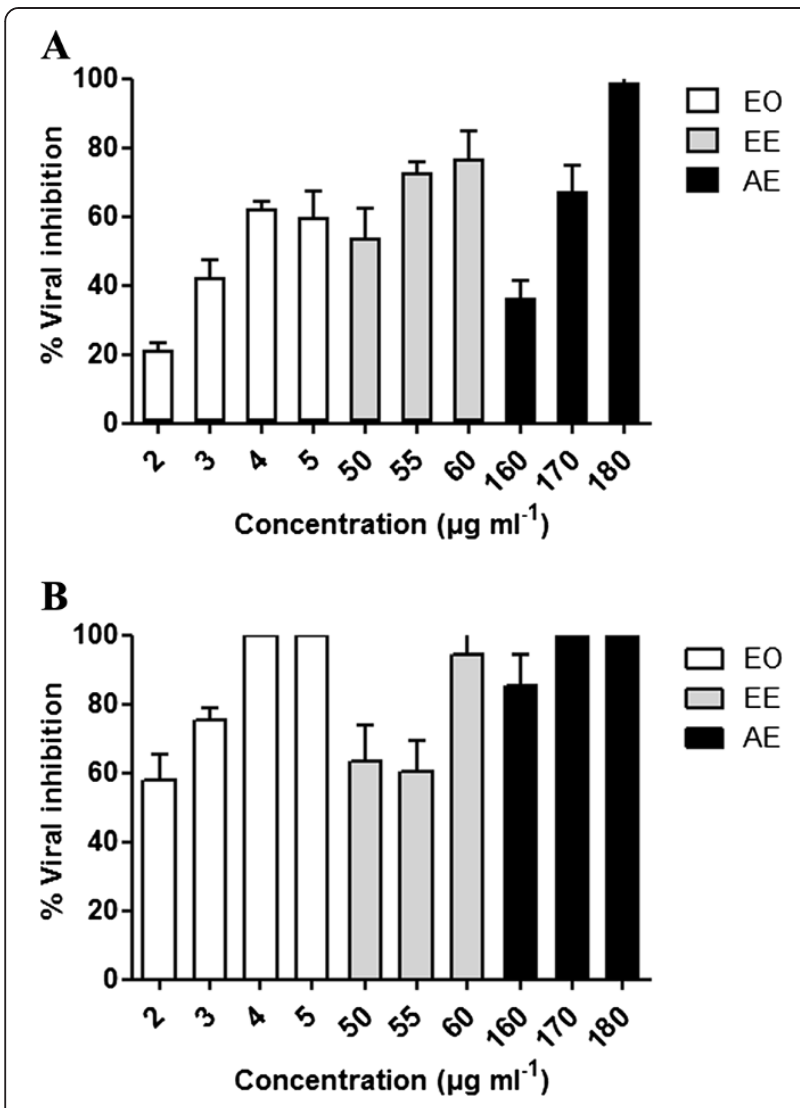

Figure 2 Percentage of viral inhibition by different Thymus capitata extracts: Essential oil $\left(2,3,4\right.$ and $\left.5 \mu \mathrm{g} \mathrm{ml}^{-1}\right)$, Ethanolic extract $\left(50,55\right.$ and $\left.60 \mathrm{\mu g} \mathrm{ml}^{-1}\right)$ and Aqueous extract (160, 170 and $180 \mu \mathrm{g} \mathrm{ml}^{-1}$ ) were tested during (A) and after (B) infection of MDBK cells with $10^{3} \mathrm{TCID}_{50} \mathrm{ml}^{-1}$ of Bovine herpesvirus type 1.

Also, Behravan et al. [14] showed that thymol and carvacrol were the major compounds in T. capitata EO from Iran. However, other studies showed geographic variations of chemical compositions of $T$. capitata extracts $[15,20]$. Nolkemper et al. [11] found that rosmarinic acid was the most abundant compound of the same genus $T$. vulgaris AE. In fact, bioactive molecule types and amount variations from $T$. capitata depend on the geographic distribution (climate, soil type), the collecting season, as well as, the plant part $[20,21]$.

In the present study, $T$. capitata extracts exhibited an in vitro cytotoxic activity with $\mathrm{CC}_{50}$ values varying from 48.70 to $298 \mu \mathrm{g} \mathrm{ml}^{-1}$, depending on the type used in the same biological conditions (Table 2). When referring to the in vitro and the predicted in vivo substance toxicity classification of Halle and Göres [22], T. capitata EO, EE and $\mathrm{AE}$ are considered to exhibit a relatively low toxicity; the most toxic extract being EO.

Cytotoxic activities of EO or its major components were demonstrated, in vitro, in mammalian cells to be moderate to high [22]. Indeed, EO induced some defects in the cell respiratory system (permeabilization of outer and inner mitochondrial membranes), usually directly associated with cell death by apoptosis and necrosis [23]. In general, the cytotoxic activity of EO is mostly due to the presence of phenols. However, flavones are the cytotoxic components present in $\mathrm{AE}$ and have been reported to exhibit cytotoxic activity at high concentrations towards normal non infected human cells [24]. Furthermore, it has been suggested that when flavonoids are introduced into cells, they increase the intracellular reactive oxygen species levels, and exert their cytotoxicity effect [24]. According to previous studies, $\mathrm{CC}_{50}$ values of $T$. vulgaris were 70 , 62.3 [12] and $62 \mu \mathrm{g} \mathrm{ml}^{-1}$ [11] for EO, EE and AE, respectively. The difference in AE chemical compositions between $T$. capitata and $T$. vulgaris may explain the observed $\mathrm{CC}_{50}$ values. The rosmarinic acid was the most abundant compound in T. vulgaris. However, for South Tunisia, T. capitata AE, apigenin and luteolin were the major compounds and rosmarinic acid was the minor extracted compound. Nolkemper et al. [11] showed that for aqueous Lamiaceae plant extracts, the $\mathrm{CC}_{50}$ varied between 55 and $125 \mu \mathrm{g} \mathrm{ml}^{-1}$ due to differences in their phenolic compounds' concentrations.

In the present study, the inhibitory effect of thyme EO against BHV-1 infection was compared to the antiviral activity of EE and AE (Table 3 ). Both T. capitata extracts were shown to affect significantly $\mathrm{BHV}-1$ replication ( $\mathrm{p}$ value $<0.05)$. Previous in vitro experiments showed similar results for $\mathrm{EO}, \mathrm{EE}$ and $\mathrm{AE}$ from Lamiaceae plant including Thymus spp. [11,12].

The thyme EO revealed a higher antiviral activity and a SI of 14.49, whereas EE and AE showed lower SIs (Table 3). The anti-herpes virus activities of several EOs of different plant sources as well as of some constituents of EOs were reported previously, e.g. peppermint oil, thyme oil and anise oil $[10,25,26]$. The presence of thymol and $\beta$-caryophyllene in EO may strongly contribute to their antiviral effect which is in agreement with our results and as described by others [14,27].

Pre-treatment of cells with different $T$. capitata extracts, at the tested concentrations, completely inhibited viral CPE (Figure 1D). In addition, an antiviral activity dose dependent effect was significantly observed (p-value < 0.05) for EO, EE and AE when added during or after cell infection (Figure 2A; B). A very significant correlation was found between $\mathrm{AE}$ concentration and viral inhibition in the interval [160, $180 \mu \mathrm{g} \mathrm{ml}^{-1}$ ]. These results suggested that these biomolecules may interfere with either viral particles and/or virus envelope, and may mask viral structures or cell receptors necessary for the virus adsorption and entry into the host cells. In fact, Schnitzler et al. [13] reported that balm oil, abundant in phenolic compounds, affected the viruses in vitro when added before viral adsorption, although the mechanism of action is 
still unknown. It is suggested that the balm oil could bind to the viral proteins involved in the host adsorption and penetration, or damage the virus envelope. In several cases, plant-derived polyphenols exhibit anti-herpesvirus activity mostly by influencing the early phases of infection [18]. Furthermore, Reichling et al. [12] concluded that ethanolic plant extracts affect herpesvirus prior to and during adsorption. They suggested that the antiviral activity is due to the association of the extracts with proteins of the host cell surface molecules, resulting in reduction or prevention of viral adsorption.

Flavonoid derivatives have also been reported to possess antiviral activity against a wide range of viruses [28-30]. Apigenin 7-O-glucoside and luteolin are flavonoid compounds that are found in lemon balm (Melissa officinalis), chamomile (Chamomilla recutita), and celery (Apium graveolens) and have shown antiviral activity in vitro $[28,31]$. The extracts of basil (Ocimum basilicum) and their purified compounds, including apigenin, were tested against a number of viruses (herpesvirus, adenovirus, and hepatitis B virus), and have displayed a broad range of antiviral action, which is in accordance with our data [32].

The mechanism of antiviral action of polyphenolic compounds is mainly due to inhibition of viral enzymes, disruption of cell receptors, prevention of viral binding and penetration into cells. Finally, some natural compounds are reported to have the capacity to interfere with herpesvirus enzymes (DNA polymerase inhibition by eugenol), and thus viral replication [33].

\section{Conclusion}

Thymus capitata EO, EE and AE affect (below cytotoxic concentration) mainly the adsorption of BHV-1 virus to Madin-Darby Bovine Kidney host cells. This activity can be explained by the presence of some flavonoids such as apigenin, luteolin or rosmarinic acid in the $\mathrm{AE}$ and the presence of polyphenols as thymol in EE and EO. During pre-treatment of MDBK cells, all tested extracts of T. capitata inhibit viral attachment to cell receptors making them good candidates against viral infection. Moreover, a dosedependent effect was recorded during and after viral infections for the three $T$. capitata extracts tested.

\footnotetext{
Abbreviations

GC/MS: Gas chromatography-mass spectrometry; HPLC/MS: Performance liquid chromatography/mass spectrometry; EO: Essential oil; EE: Ethanolic extract; AE: Aqueous extract; BHV-1: Bovine herpesvirus type 1; DMEM: Dulbecco's modified Eagle's medium; DMSO: Dimethylsulfoxide; MNTC: Maximum non-toxic concentration; MDBK: Madin-Darby Bovine Kidney; CPE: Cytopathic effect; $\mathrm{TCID}_{50}$ : The 50\% Tissue Culture Infective Dose; $\mathrm{IC}_{50}$ : The $50 \%$ effective antiviral concentration; $\mathrm{CC}_{50}$ : The $50 \%$ cytotoxic concentration; SI: The selectivity index.
}

\section{Competing interests}

The authors declare that they have no competing interests.

\section{Authors' contributions}

RB-E, MM-T, BK, IL, M-FD, MG, HA, FB, and A-JG designed the study and participated in plant selection and collection, spectral analyses and in the drafting and correction of the manuscript., RB-E, MM-T, BK, IL, M-FD, FB and A-JG performed GC/SM, HPLC/SM analyses of the plant extracts and carried out the cytotoxicity and antiviral assay. They also contributed to data analysis and critically revised the manuscript. All the authors read and approved the final manuscript version.

\section{Acknowledgements}

This work received financial support from the «Laboratoire d'épidémiologie et microbiologie vétérinaire », Institut Pasteur of Tunis (Ministère de l'enseignement supérieur et de la recherche, Tunisia).

\section{Author details}

${ }^{1}$ Université Tunis El Manar, Laboratoire d'Epidémiologie et Microbiologie Vétérinaire, Institut Pasteur de Tunis, Place Pasteur BP 74, 1002 Tunis, Tunisia. ¿Université de la Manouba, Institut Supérieur de Biotechnologie, BiotechPôle, BP-66, 2020 Sidi Thabet, Tunisia. ${ }^{3}$ Université de la Manouba, Laboratoire de Parasitologie, École Nationale de Médecine Vétérinaire de Sidi Thabet, 2020 Sidi Thabet, Tunisia. ${ }^{4}$ Université de la Manouba, Laboratoire des Substances Naturelles, Institut National de Recherche et d'Analyse Physico-chimique Pôle Technologique Sidi Thabet, 2020 Sidi Thabet, Tunisia.

Received: 1 May 2014 Accepted: 22 September 2014

Published online: 27 September 2014

\section{References}

1. Biswas S, Bandyopadhyay S, Dimri U, Patra PH: Bovine herpesvirus-1 (BHV-1) - a re-emerging concern in livestock: a revisit to its biology, epidemiology, diagnosis, and prophylaxis. Vet Quarterly 2013, 33:68-81.

2. Jones C, Chowdhury S: Bovine herpesvirus type 1 (BHV-1) is an important cofactor in the bovine respiratory disease complex. Vet Clin North Am Food Anim Pract 2010, 26:303-321.

3. del Barrio G, Parra F: Evaluation of the antiviral activity of an aqueous extract from Phyllanthus orbicularis. J Ethnopharmacol 2000, 72:317-322.

4. Simoni IC, Manha APS, Sciessere L, Hoe VMH, Takinami VH, Fernandes MJB: Evaluation of the antiviral activity of Brazilian cerrado plants against animal viruses. Virus Rev Res 2007, 12:25-31.

5. Melo FL, Benati FJ, Junior WAR, Mello JCP, Nozaw C, Carvalho Linhares RE: The in vitro antiviral activity of an aliphatic nitro compound from Heteropteris aphrodisiaca. Microbiol Res 2008, 163:136-139.

6. Gupta D, Goel A, Bhatia AK: Studies on antiviral property of Acacia nilotica. J Env Res Dev 2010, 5:141-152.

7. Pilau MR, Alves SH, Weiblen R, Arenhart S, Cueto AP, Lovato LT: Antiviral activity of the Lippia graveolens (mexican oregano) essential oil and its main compound carvacrol against human and animal viruses. Braz J Microbiol 2011, 42:1616-1624.

8. Barros AV, Araújo LM, Oliveira FF, Conceição AO, Simoni IC, Fernandes MJB, Arns CW: In vitro evaluation of the antiviral potential of Guettarda angelica against animal herpesviruses. Acta Scientiae Veterinariae 2012, 40:1068-1075.

9. Fernandes MJB, Barros AV, Melo MS, Simoni IC: Screening of Brazilian plants for antiviral activity against animal herpesviruses. J Med Plants Res 2012, 6:2261-2265.

10. Abdallah FM, Sobhy H, Enan G: Evaluation of antiviral activity of selected anise oil as an essential oil against Bovine herpesvirus type -1 in vitro. Glob Veterinaria 2013, 10:496-499.

11. Nolkemper S, Reichling J, Stintzing FC, Carle R, Schnitzler P: Antiviral effect of aqueous extracts from species of the Lamiaceae family against herpes simplex virus type 1 and type 2 in vitro. Planta Med 2006, 72:1378-1382.

12. Reichling J, Nolkemper S, Stintzing FC, Schnitzler P: Impact of ethanolic lamiaceae extracts on herpes virus infectivity in cell culture. Forsch Komplementmed 2008, 15:313-320.

13. Schnitzler P, Schuhmacher A, Astani A, Reichling J: Melissa officinalis oil affects infectivity of enveloped herpesviruses. Phytomed 2008, 15:734-740.

14. Behravan J, Ramezani M, Nobandegani FE, Gharaee ME: Antiviral and antimicrobial activity of Thymus transcaspicus essential oil. Pharmacol Online 2011, 1:1190-1199. 
15. Jabri-Karoui I, Bettaieb I, Msaada K, Hammami M, Marzouk B: Research on the phenolic compounds and antioxidant activities of Tunisian Thymus capitata. J Funct Foods 2012, 4:66-69.

16. Boubaker Elandalousi R, Akkari H, B'chir F, Gharbi M, Mhadhbi M, Awadi S, Darghouth MA: Thymus capitata from Tunisian arid zone: chemical composition and in vitro anthelmintic effects on Haemonchus contortus. Vet Parasitol 2013, 197:374-378.

17. Reed IJ, Muench H: A simple method of estimating fifty per cent endpoints. Am J Epidemiol 1938, 27:493-497.

18. Chattopadhyay D, Chawla Sarkar M, Chatterjee T, Dey R, Bag P, Chakrabarty S, Khan MTH: Recent advancements for the evaluation of antiviral activities of natural products. New Biotechnol 2009, 25:347-368.

19. Mkaddem MG, Romdhane M, Ibrahim H, Ennajar M, Lebrihi A, Mathieu F, Bouajila J: Essential oil of Thymus capitata Hoff. et Link. from Matmata, Tunisia: gas chromatography-mass spectrometry analysis and antimicrobial and antioxidant activities. J Med Food 2009, 13:1500-1504.

20. Saei-Dehkordi SS, Tajik H, Moradi M, Khalighi-Sigaroodi F: Chemical composition of essential oils in Zataria multiflora Boiss. from different parts of Iran and their radical scavenging and antimicrobial activity. Food Chem Toxicol 2010, 48:1562-1567.

21. Loziene K, Venskutonis PR: Influence of environmental and genetic factors on the stability of essential oil composition of Thymus pulegioides. Biochem Syst Ecol 2005, 33:517-525.

22. Halle W, Göres E: Prediction of $L_{50}$ values by cell culture. Pharmazie 1987, 42:245-248

23. Bakkali F, Averbeck S, Averbeck D, Idaomar M: Biological effects of essential oils - a review. Food Chem Toxicol 2008, 46:446-475.

24. Matsuo M, Sasaki N, Saga K, Kaneko T: Cytotoxicity of flavonoids toward cultured normal human cells. Biol Pharm Bull 2005, 28:253-259.

25. Schuhmacher A, Reichling J, Schnitzler P: Virucidal effect of peppermint oil on the enveloped viruses herpes simplex virus type 1 and 2 in vitro. Phytomed 2003, 10:504-510.

26. Koch C, Reichling J, Schneele J, Schnitzler P: Inhibitory effect of essential oils against herpes simplex virus type 2. Phytomed 2008, 15:71-78.

27. Astani A, Reichling J, Schnitzler P: Screening for antiviral activities of isolated compounds from essential oils. Evid Base Complement Altern Med 2011, 44:8-15

28. Akula SM, Hurley DJ, Wixon RL, Wang C, Chase CC: Effect of genistein on replication of bovine herpesvirus type 1. Am J Vet Res 2002, 63:1124-1128.

29. Nowakowska Z: A review of anti-infective and anti-inflammatory chalcones. Eur J Med Chem 2007, 42:125-137.

30. Özçelik B, Kartal M, Orhan I: Cytotoxicity, antiviral and antimicrobial activities of alkaloids, flavonoids, and phenolic acids. Pharm Biol 2011, 49:396-402.

31. Andres A, Donovan SM, Kuhlenschmidt MS: Current Topics Soy isoflavones and virus infections. J Nutr Biochem 2009, 20:563-569.

32. Chiang LC, Ng LT, Cheng PW, Chiang W, Lin CC: Antiviral activities of extracts and selected pure constituents of Ocimum basilicum. Clin Exp Pharmacol Physiol 2005, 32:811-816.

33. Felipe AMM, Rincão VP, Benati FJ, Linhares REC, Galina KJ, de Toledo CEM, Lopes GC, de Mello JCP, Nozawa C: Antiviral effect of Guazuma ulmifolia and Stryphnodendron adstringens on poliovirus and bovine herpesvirus. Biol Pharm Bull 2006, 29:1092-1095.

doi:10.1186/s12917-014-0231-6

Cite this article as: Boubaker-Elandalousi et al:: Non-cytotoxic Thymus capitata extracts prevent Bovine herpesvirus-1 infection in cell cultures. BMC Veterinary Research 2014 10:231.

\section{Submit your next manuscript to BioMed Central and take full advantage of:}

- Convenient online submission

- Thorough peer review

- No space constraints or color figure charges

- Immediate publication on acceptance

- Inclusion in PubMed, CAS, Scopus and Google Scholar

- Research which is freely available for redistribution

Submit your manuscript at www.biomedcentral.com/submit 